\title{
小児嗄声の臨床統計
}

一予後を中心に一

湯本 英二・丘村＼cjkstart熙

\section{Long Term Prognosis of Hoarseness in School-Children}

\author{
Eiji Yumoto and Hiroshi Okamura
}

(Ehime University)

Laryngeal pathology, which causes so-called school-age hoarseness, includes swelling and nodules of the vocal folds. The authors followed eight children with swollen vocal folds, 27 with nodules and nine whose nodules had been removed microsurgically. All these children received vocal hygiene therapy. Two of the eight children with swollen vocal folds recovered and two others developed vocal fold nodules. The other four had fluctuating hoarseness. Nineteen of the 27 with nodules recovered and four others developed swollen vocal folds. The other four remained unchanged. Vocal hygiene therapy seemed helpful because 11 of the 19 recovered within two months. Five of the nine who had been operated on had an uneventful course; the vocal folds became swollen again in the other four. Vocal fold nodules recurred in one of these four children with swollen vocal folds.

Key words: school-age hoarseness, long term prognosis, vocal hygiene, laryngomicrosurgery

\section{はじめに}

幼児や学童で，声の乱用 (vocal abuse) すな わち大声でよく騒ぐなどという習慣があると嗄 声をきたすととがあり，小児嗄声あるいは学童 嗄声と呼ばれる。一般にスポーツ好きの活発な 小児に多い。いわゆる声帯浮腫の状態で, 病変 が声帯膜様部の中央に限局した結節型と, 声帯

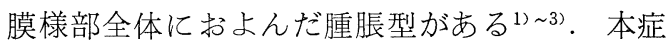
の予後は一般に良好で変声期の経過とともに自 然に軽快する例の多いことが知られている( 5). しかし嗄声を訴えて受診した患児の長期にわた る予後についての報告は少ない，今回，著者ら の施設を受部した患児の予後を，結節型・腫脹
型の病型別に，また前者については手術施行例 と非施行例に分けて経過を観察したのでその結 果を報告する。

\section{対象と方法}

$$
\text { (1) 対 象 }
$$

1976年10月から1988年 3 月までの 11 年半の間 に当科を受詅した15歳未満の小児嗄声症例は 101 例であった。このうち 6 力月以上経過を観 察できた, 腫脹型 8 例, 結節型非手術例27例, および結節型手術施行例 9 例の計44例を対象之 した.

（2）治療方針と経過観察

腫脹型・結節型ともまず保存的治療をおこな 
う。すなわち，(1)可能な限り大声・叫声を避け るとと, (2)硬起声を避けるとと, (3)上気道感染 時には早期に適切な医療を受けること，を指示 し「声の衛生」を指導する。しかし，結節型の 症例の内，(1)初診時にすでに殆ど失声状態で通 常の日常生活・学業生活に著しい支障をきたす 場合や，(2)嗄声が高度で，結節が線維化した硬 い例で，声の衛生の指導のみでは軽快しない場 合には挿管全身麻酔下に喉頭微細手術を沶こな い結節を鉗除する。退院後む再発予防のため, 声の衛生を引続き指導する.

経過観察は年 $2 \sim 3$ 回長期休㗇時におこなっ ている. 但し, 初䛦時と手術施行後は $2 \sim 4$ 週 後に再診し，以後は他の症例と同様の間隔で経 過を観察している。

\section{結 果}

表 1 亿小児嗄声症例101例の年齿別, 病型別の 分布を示す. 年齢別では $5 \sim 6$ 歳から急増し,

表 1 小㮐嗄声症例の年齢別・病型別分布

\begin{tabular}{|c|c|c|c|c|c|}
\hline & \multicolumn{2}{|c|}{ 腫 脹 型 } & \multicolumn{2}{|c|}{ 結 節 型 } & \multirow{2}{*}{ 計 } \\
\hline & 男 & 女 & 男 & 女 & \\
\hline $0 \sim 2$ 歳 & 0 & 0 & 1 & 0 & 1 \\
\hline $3 \sim 4$ & 2 & 2 & 1 & 0 & 5 \\
\hline $5 \sim 6$ & 5 & 4 & $12(1)$ & 1 & $22(1)$ \\
\hline $7 \sim 8$ & 10 & 2 & $16(3)$ & $4(1)$ & $32(4)$ \\
\hline $9 \sim 10$ & 4 & 1 & $19(3)$ & 1(1) & $25(4)$ \\
\hline $11 \sim 12$ & 2 & 2 & 3 & 3 & 10 \\
\hline $13 \sim 14$ & 0 & 0 & $2(1)$ & 4 & $6(1)$ \\
\hline 計 & 23 & 11 & $54(8)$ & $13(2)$ & $101(10)$ \\
\hline
\end{tabular}

表 2 腫脹型 8 例（男子 7 例，女子 1 例）の予後

\begin{tabular}{|c|c|c|c|c|}
\hline 予 & 後 & 年歯令 & 性 & 間 \\
\hline \multicolumn{2}{|l|}{ 治癒 } & 9 & 男 & 2 年 \\
\hline \multicolumn{2}{|l|}{ 軽快 } & 11 & 女 & 6 力月 \\
\hline \multirow{3}{*}{\multicolumn{2}{|c|}{ 不変 }} & 3 & 男 & 7 力月 \\
\hline & & 5 & 男 & 1 年 9 力月 \\
\hline & & 7 & 男 & 2 年 3 力月 \\
\hline \multirow{2}{*}{\multicolumn{2}{|c|}{ 結節型 }} & 7 & 男 & 1 年10力月 \\
\hline & & 11 & 男 & 2 年 6 力月 \\
\hline \multicolumn{2}{|c|}{ 結節型 $\rightarrow$ 腫脹型 } & 5 & 男 & 1 年 $\rightarrow 2$ 年 \\
\hline
\end{tabular}

7 〜歳でピークを示した。また，11歳以後急 激に減少した。性別では男子77例，女子 24 例之 男子が女子の 3 倍強であった。腫脹型34例，結 節型67例と結節型病変が約 2 倍であった．結節 型では男子 54 例，女子 13 例之男子が女子の約 4 倍を占めた。逆に腫脹型では男子23例女子11例 と患児全体の割合からみてやや女子に多かった (但し統計学的には有意でない).

腫脹型 8 例（男子 7 例，女子 1 例）の予後を 表 2 亿示す. 治癒 1 例, 軽快 1 例, 不変 3 例, 結節型への移行 2 例，一度は結節型に移行した ものの再び腫脹型を呈するようになったものが 1 例であった。なお，表中の「期間」は不変群 では経過観察期間，他は各々の経過を確認する までの期間を示す．以下，表 3 屯同様である.

結節型非手術例 27 例（男子 22 例，女子 5 例）

表 3 結節型非手術例27例（男子22例， 女子 5 例）の予後

\begin{tabular}{|c|c|c|c|}
\hline 後 & 年＼cjkstart齢 & 性 & 間 \\
\hline \multirow[t]{6}{*}{ 治療 } & 4 & 男 & 1 力月 \\
\hline & 5 & 男 & 8 力月 \\
\hline & 6 & 男 & 2 力月 \\
\hline & 7 & 男 & 7 カ月 \\
\hline & 14 & 女 & 2 週 \\
\hline & 15 & 女 & 3 週 \\
\hline \multirow{2}{*}{$\begin{array}{c}\text { 腫脹型 } \rightarrow \text { 治療 } \\
\text { ( } 2 \text { 例 })\end{array}$} & 7 & 男 & 2 力月 $\rightarrow 8$ 力月 \\
\hline & 9 & 男 & 3 力月 $\rightarrow 5$ 力月 \\
\hline \multirow[t]{8}{*}{ 軽快 } & 6 ( 2 例) & 男 & 1 力月, 2 力月 \\
\hline & 8 ( 2 例) & 男 & 1 力月, 3 年 \\
\hline & 9 ( 3 例) & 男 & $\begin{array}{l}2 \text { 週, } 1 \text { 力月, } \\
1 \text { 力月 }\end{array}$ \\
\hline & 10 ( 2 例) & 男 & 4 力月, 6 力月 \\
\hline & 12 & 男 & 4 力月 \\
\hline & 8 & 女 & 1 年 \\
\hline & 12 & 女 & 4 週 \\
\hline & 13 & 女 & 4 力月 \\
\hline \multirow[t]{3}{*}{ 不変 } & 7 & 男 & 1 年 5 カ月 \\
\hline & 9 & 男 & 1 年 4 力月 \\
\hline & 13 & 男 & 6 力月 \\
\hline 腫脹型 & 2 & 男 & 2 力月 \\
\hline （2 例 $)$ & 7 & 男 & 5 力月 \\
\hline $\begin{array}{c}\text { 軽快 } \rightarrow \text { 悪化 } \rightarrow \text { 軽快 } \\
(1 \text { 例 })\end{array}$ & 6 & 男 & $\begin{array}{l}6 \text { 力月 } \rightarrow 9 \text { 力月 } \\
\rightarrow 1 \text { 年 } 4 \text { 力月 }\end{array}$ \\
\hline
\end{tabular}


の予後を表 3 に示す。治癒 6 例, 腫脹型を経て 治癒 2 例, 軽快 13 例, 不変 3 例, 腫脹型に移行 2 例, 軽快と悪化を反復 1 例であった。治瘾 6 例の治瘾までに要した期間は 2 週〜 8 力月と一 定しないが，4 例は 2 力月以内と比較的短期間 であった．腫脹型を経て治瘾した 2 例は腫脹型 を呈するまでが 2 ～ 3 力月，治癒するまでさら に 5 〜 8 カ月と長期間を要した. 軽快 13 例の軽 快までに要した期間は 2 週〜 3 年と一定しない. しかし 7 例は 2 力月以内と比較的短期間に軽快 しており, 治瘾群と同椂に, 早期に軽快する群 と長期間を要する群に分けられた。 なお女子 5 例はいずれも治癒あるいは軽快群に入った。

結節型手術施行例 9 例（男子 7 例，女子 2 例）の予後を表 4 亿示す. 表中の期間は退院後 の声帯の変化を確認するまでの期間である. 半 年以上再発しなかったのは女子 2 例を含む 5 例 であった. 腫脹型に移行 3 例, 腫脹型を経て結 節型に移行 1 例であった. 腫脹型を呈するまで の期間は 2 例が 2 週， 1 例が 1 力月と術後早期 であった。他の 1 例は術後しばらく順調であっ たが 3 年後に腫脹型を呈するに至った. 2 週後 に腫脹型を呈した 2 例中 1 例は 1 年後に結節が 再発した。

\section{考按}

声帯結節は声帯膜様部ほぼ中央の部位に両側 性に生じる小結節隆起で, 歌手・教師など音声 を過度に使用する人や小児で大声でしゃべる者

表 4 結節型手術施行例 9 例（男子 7 例, 女子 2 例）の予後

\begin{tabular}{ccll}
\hline 予 後 & 年齢 & 性 & \multicolumn{1}{c}{ 期 } \\
\hline 再発なし & 6 & 男 & \\
$(5$ 例 $)$ & 8 & 女 & \\
& 9 & 女 & \\
& 10 & 男 & \\
& 13 & 男 & \\
腫脹型 & 8 & 男 & 2 週 \\
$(3$ 例 $)$ & 8 & 男 & 3 年 \\
& 9 & 男 & 1 カ月 \\
腫脹型 $\rightarrow$ 結節型 & 7 & 男 & 2 週 $\rightarrow 1$ 年 \\
(1 例 $)$ & & &
\end{tabular}

に起こり易いとされている6 . 成人では女性に， 小児では男子に多いてとが知られているがその 理由はいまだ明らかにされていない。また，小 児嗄声例の中には結節を生じた例以外に声帯の び慢性腫脹を認める例がある，石井は1てのよ うな病変を「浮腫型」, 新美は3「浮腫肥大型」 之呼んだが，著者らは以前から「腫脹型」と命 名して報告してきた277.いずれにせよ小児嗄声 例の喉頭所見は結節型と腫脹型の二種類に分類 される.さらに，同一症例の経過中には両型間 の移行が観察される場合があり両者は互いに関 連した病変である。一方，成人では小児にみら れる腫脹型病変はまったく観察されない，中高 年の女性に多いポリープ様声帯と屯異なるし， あちろんポリープ様声带と結節との間の移行む ない．乙れらの事実から成人と小児の結節は区 別して扱うべきあのと考えられる.

表 1 に示したように，小児嗄声例は 5 〜 歳 から急増, 7 〜 歳でピークとなり, 11歳以後 急激に減少した。広戸らは8 嗄声児の $27 \%$, 石 井は1 $23 \%$ に声帯の浮腫を認めたとしている. 著者らの施設では腫脹型を呈したのは患児全体 の34\%であった。広戸らや石井のいう嗄声児に は炎症等によると思われる例が含まれていると とを考慮すると，小児嗄声例の $25 \sim 35 \%$ が腫脹 型，残りが結節型と推定される．著者らの施設 では，男子が 77 例と小児嗄声全体の $3 / 4$ 以上 を占めた。しかし腫脹型をみると男子（23例） に比し女子（11例）が患児全体の割合からみて 多く，逆に結節型では男子（54例）が女子（13 例）の4倍と男子に多かった。 但してれらの関 係には統計学的有意差はなかった。

小児嗄声に関する従来の報告は1225)8)，2名 の少年合唱団員の結節の消失経過の報告9) を除 くと, ある時点における断面的な観察が大部分 である. 広戸らは4) 小学校 5 年生児童を 3 年間 検診し間接喉頭鏡所見が児童全体としてどう変 化したかを述べた。 また角田らは10)アンケート によって患児の予後を調查し初診時に比し大部 分 (28例中22例) の例は変声後は音声が改善し 
たと報告した。しかし両報告とも個々の患児の 病変がどのように推移したかについては明らか にしていない。著者らの調査によれば，腫脹型 8 例の予後は治癒または軽快が各 1 例, 結節型 への移行が 2 例, 他の 4 例は不変または軽快と 悪化を繰り返した例であった。治癒または軽快 までの期間は 2 年， 6 力月と長期にわたったと と， 6 例が不変または結節型への移行を示した ことから，腫脹型に対する「声の衛生」の指導 は有効でなかったか，あるいは守られていなか ったものと考えられた。

結節型非手術群 27 例の予後は治瘺または軽快 がそれぞれ 6 例, 13例, 腫脹型への移行が 4 例, 他の 4 例は不变または軽快と悪化を繰り返した 例であった。なお腫脹型へ移行した 4 例中 2 例 は 5 力月後, 8 力月後に治癒した. 治癒 6 例, 軽快13例中，治癒または軽快を確認するまでの 期間は 1 力月以内が 9 例 (47\%), 2 力月以内が 11 例（58\%）と多数であった。 このととから 「声の衛生」の指導が結節型嗄声例には有効で あったと考えられる. 腫脹型に移行した 4 例の 移行までの期間は $2 \sim 5$ 力月でてのうち最終的 に治癒した 2 例はさらに 5 力月， 8 力月を要し た. 先述した腫脹型の予後と考え合わせると， 腫脹型嗄声例は治癒または軽快に比較的長期間 を要すると考えられる．また女子（腫脹型 1 例， 結節型非手術群 5 例）は全例とも軽快または治 瘺しており女子の予後は一般に良好といえる。

結節型手術施行群 9 例の予後は, 6 力月以上 再発のなかったのが 5 例, 腫脹型を呈したもの が 4 例で内 1 例は結節型に移行した。 この 4 例 中 3 例は術後 1 力月以内に腫脹型を呈した。他 の 1 例は術後順調に経過していたが 3 年後に腫 脹型を呈した。乙の 4 例はすべて男子で 7 〜 歳であった。再発のなかった 5 例中 2 例が女子, 残り 3 例（男子）の年齢は 2 例が 10 歳以上で変 声前であった。 また，一般に男子では変声期の 経過とと屯に自然に軽快する例の多いことが知 られている ${ }^{45}$. . しかし腫脹型から結節型に移 行した 2 例の内の 1 例は13歳時であり, 結節型

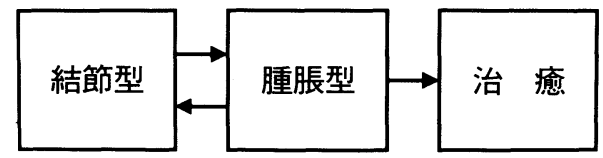

図1 腫脹型を呈した小児嗄声例の経過パタン

非手術例で 6 力月以上不変であった 3 例中 1 例 は13歳であった。このように必ずしも全例が良 好な経過をたどるわけではないととあ銘記して おかねばならない。

結節型と腫脹型の間には経過観察中に互いに 移行する例が観察された。腫脹型群 8 例中結節 型への移行は 3 例 $(37.5 \%)$ ， 結節型非手術 群27例中腫脹型への移行は 4 例（14.8\%）にみ られた。結節型非手術群で腫脹型に移行した 4 例中 2 例は後に治癒している。しかし腫脹型群 から結節型に移行した 3 例ではその後治瘜した 例はない。すなわち，腫脹型から結節型に移行 した後に治瘾した例はみられず，従って腫脹型 を呈した例は図 1 のような経過のパタンをとる 可能性が高いと考えられた。図 1 亿示す，腫脹 型群の経過パタンからは, 腫脹型は結節型の前 段階あるいは軽症型とも考えられる。一方, 初 診時すでに結節を呈した例では腫脹型を経て治 瘾した例（2 例）と腫脹型を経ずに治癒した例 （6 例）がある。必ず図 1 のように腫脹型を経 て結節が治癒するのでなく，結節が次第に縮小 しやがて消失する過程があるととは経過観察時 の喉頭所見から明らかである. 今後, 症例数を 増やしてさらに㭘討すべき課題である.

\section{まとめ}

当科を受診した小児嗄声症例の内， 6 力月以 上経過を観察できた腫脹型 8 例, 結節型非手術 例27例，および結節型手術施行例 9 例の計 44 例 を対象に各々の経過を観察し以下の結果を得た

（1）腫脹型 8 例の予後は治癒または軽快が 各 1 例, 結節型への移行が 2 例, 他の 4 例は不 変または軽快と悪化を繰り返した例であった。 治癒または軽快までの期間は 2 年， 6 力月と長 期間であった。 6 例が不変または結節型へ移行 した。 
（2）結節型非手術群27例の予後は治瘾 6 例, 軽快 13 例, 腫脹型への移行 4 例, 不変または軽 快と悪化を繰り返した例が 4 例であった。治癒 または軽快した19例中11例（58\%）が 2 力月以 内の経過であり「声の衛生」の指導が有効であ ったと考えられた。

（3）結節型手術施行群 9 例の予後は再発な し 5 例, 腫脹型へ移行 4 例で内 1 例は後に結節 が再発した.

（4）女子（腫脹型 1 例, 結節型非手術群 5 例）は全例とも軽快または治癒した。また手術 を施行した女子 2 例とも再発がなかった。一般 に男子では変声期の経過とともに自然に軽快す る例の多いことが知られているが，必ずしも全 例が良好な経過をたごるわけではなかった。

\section{参考文献}

1 ）石井末之助：小児嗄声について一特に “声変前喉 頭” の再検討と Sino-Laryngitis の提唱. 耳展 $15: 289 \sim 307,1972$.

2）丘村 熙：小児嗄声の治療方針. 耳鼻 $26: 740$ $742,1980$.

3) 新美成二：小児嗄声の取り扱い.コミュニケーシ ヨン障害（野村恭也，本庄 篇編）．10１8頁, 金
原出版, 東京, 1987.

4 ) 広戸幾一郎, 平野 実, 中村 任, 他: 学童の嗄 声の経時的変化に関する統計的観察. 耳鼻臨床 $56: 247 \sim 252,1963$.

5 ) 前川彦右エ門, 伊藤督夫, 渡辺とし子, 他 : 学童 嗄声についての観察. 日耳鼻 $76: 1459 \sim 1471$, 1973.

6) 切替一郎 : 謡人結節. 新耳鼻咽喉科学. 448 449 頁, 南山堂, 東京, 1972 .

7 ）丘村 熙：小児結節の治療方針. 耳鼻 29：956～ 957, 1983.

8 ）広戸幾一郎, 中村 任, 平野 実: 学童の音声 に関する統計的観察--. 耳鼻臨床 $53: 756 \sim 761$, 1960.

9 ) 原田利治 : 学童の声帯結節の運命一二人の少年合 唱団員についての観察一. 聴覚言語障害 3:37〜 42, 1974 .

10）角田晃一，新美成二，広瀬 肇，他：小児嗄声の 予後の検討. 日耳鼻 $91: 1892 \sim 1897 ， 1988$.

$\left(\begin{array}{l}\text { 原稿採択 : 平成元年 } 5 \text { 月 } 31 \text { 日 } \\ \text { 別刷請求先 : 湯本英二 } \\ \text { 厂791-02 愛媛県温泉郡重信町志津川 } 454 \\ \text { 愛媛大学医学部耳鼻咽喉科学教室 }\end{array}\right)$

